\title{
YIELD AND YIELD ATTRIBUTES OF SHORT DURATION MUSTARD AS INFLUENCED BY NUTRIENT RATES
}

\author{
K.K. Ahmed ${ }^{1}$, B. Karmakar ${ }^{1 *}$, B. Ahmed ${ }^{1}$, S. Akter ${ }^{2}$ and M.S. Islam ${ }^{3}$ \\ ${ }^{1}$ Adaptive Research Division, Bangladesh Rice Research Institute, Gazipur, Bangladesh. \\ ${ }^{2}$ Khulna University, Khulna, Bangladesh. \\ ${ }^{3}$ Bangabandhu Sheikh Mujibur Rahman Agricultural University, Gazipur, Bangladesh. \\ *Corresponding E-mail: biswajitbrri@gmail.com
}

Keywords: Mustard, yield, siliqua, dry matter, BARI Sarisha-14

\begin{abstract}
Mustard (Brassica napus)is the important principal edible oil-producing crop in Bangladesh. However, the nutrient requirement of mustard especially for the short duration variety is very much important to obtain higher yield. A field experiment was conducted to assess the requirement of major nutrients $(\mathrm{N}, \mathrm{P}, \mathrm{K}$, and $\mathrm{S})$, and to recommend fertilizers for short-duration mustard variety BARI Sarisha-14. There were 8 treatments $\mathrm{T}_{1}=100 \%$ soil test based (STB) nutrients (N, P, K, S, Zn \& B @ 90, 25, 60, 15, $2 \& 1 \mathrm{~kg} \mathrm{ha}^{-1}$, respectively) as per Fertilizer Recommendation Guide (FRG,2012), $\mathrm{T}_{2}=\mathrm{T}_{1}+$ $25 \% \mathrm{~N}$ of FRG, $\mathrm{T}_{3}=\mathrm{T}_{1}+25 \% \mathrm{NP}$ of $\mathrm{FRG}, \mathrm{T}_{4}=\mathrm{T}_{1}+25 \% \mathrm{NK}$ of $\mathrm{FRG}, \mathrm{T}_{5}=\mathrm{T}_{1}+25 \%$ PK of FRG, $\mathrm{T}_{6}=\mathrm{T}_{1}+25 \%$ NPK of FRG, $\mathrm{T}_{7}=75 \%$ of $\mathrm{T}_{1}$ and $\mathrm{T}_{8}=$ native nutrient (control). The experiment was laid out in Randomized Complete Block Design with 3 replications. The results revealed that yield and yield parameters of mustard weresignificantly influenced by the nutrient levels. The highest value of almost all the yield components and yield were obtained in T6 among the treatments. The highest seed yield $\left(1.68 \mathrm{tha}^{-1}\right)$ and the maximum stover yield $\left(2.96 \mathrm{t} \mathrm{ha}^{-1}\right)$ were obtained from the treatment $\left(\mathrm{T}_{6}\right)$ containing $100 \%$ STB nutrients with additional 25\% NPK among the fertilizer treatments. The seed yield value was statistically higher than all other treatments except the treatment where $100 \%$ STB nutrients with additional $25 \% \mathrm{NP}$ were used $\left(\mathrm{T}_{3}\right)$. The highest seed yield and stover production were attributed tothe yield contributing parameters. The highest amount of all the nutrients content was found in the treatment $T_{6}$ that was followed by $T_{3}$ and $\mathrm{T}_{4}$ and the lowest in $\mathrm{T}_{8}$. The highest amount of $\mathrm{N}, \mathrm{P}, \mathrm{K}$, and $\mathrm{S}$ content in seed of the treatment $\mathrm{T}_{6}$ was $3.75,0.97,0.96$ and $0.78 \%$, respectively. The highest yield was accredited to the highest amount of nutrient content in seed. It could be concluded that the treatment T6 (STB fertilizer dose $+25 \%$ NPK of FRG) would suitable for short duration Mustard (BARI Sarisha-14) for getting higher yield and better performance.
\end{abstract}

\section{Introduction}

Mustard (Brassica napus A.) belonging to the family Brassicaceaeis one of the most important oilseed crops throughout the world after soybean (S.N.) and groundnut (S.N.). Among the oilseed crops grown in Bangladesh mustard holds the first position in terms of both total cultivation area and production. A total area of 3,36,542ha in Bangladesh is used for mustard production with an annual production of about 3,62,860 metric ton (BBS, 2018). It is cultivated in Bangladesh and covers a good acreage; however, the yield is not satisfactory due to low yield as well as nutrient mining, depletion of soil organic matter, imbalanced fertilization, scanty use of bio and organic fertilizers, and poor management practices (Miah and Karim, 1995).

The correct application of nutrients is essential for the maximization of farm income, economic and quality product, and environmental improvement. The amount of fertilizers applied should be based on diagnostic methods. Any fertilizer recommendation should consider the cost of fertilizer and its 
application, as well as the value of the product (Sawedaet al., 2017).The fertility status of Bangladesh soil is most uneven and it varies considerably even between two adjacent plots. Fertilization of farm plots through soil analysis might be aneffective way to achieve maximum yield goal with economic benefit, to maintain soil fertility, and to avoid environmental pollution.

Bangladesh Agricultural Research Institute (BARI) has recently developed a short-duration mustard variety (BARI Sarisha-14) having a life spell of about 75 to 80 days with seed yield is about 1.4-1.6 $t$ $\mathrm{ha}^{-1}$ which can be fitted easily in the existing cropping pattern. As such Soil Science Division of BARI is trying to fit this mustard variety in the Mustard-Mungbean-T.Aus-T.Aman cropping pattern. As a result assessment of its nutrient requirement for optimum yield through soil test based (STB) is of utmost importance. Therefore, the study was undertaken to investigate the nutrient requirement based on soil test and to recommend fertilizer recommendation for short-duration mustard var.BARI Sarisha14.

\section{Materials and Methods}

The experiment was conducted at the central research farm of Bangladesh Agricultural Research Institute (BARI), Joydebpur, Gazipur(24.09 $\mathrm{N}$ latitude and $90.26^{\circ} \mathrm{E}$ longitude and $8.4 \mathrm{~m}$ altitude) during Rabi season of 2013-2014 to find out the requirement of nutrient such as N, P, K, S for BARI Sarisha-14. The experimental site belongs to the Agro-ecological Zone (AEZ) 28 which is characterized by clay within $50 \mathrm{~cm}$ from the surface and is acidic and it belongs to Chhiata series and has been classified as Grey Terrace Soils (FRG, 2018). The nutritional status of the experimental field is presented in Table 1.It is characterized by comparatively high rainfall, high humidity, high temperature, relatively long day period during April to September and scanty rainfall, low humidity, low temperature, and short-day period fromOctober to March.The experiment was laid out in Randomized Complete Block Design (RCBD) with three replications. The unit plot size was $4 \mathrm{~m} \times 3 \mathrm{~m}$ and the seeds were sown continuouslyat the rate of $8 \mathrm{~kg} \mathrm{ha}^{-1}$ in rows. Row to row spacing was $30 \mathrm{~cm}$. Eight treatments $\mathrm{T}_{1}=100 \%$ soil test based (STB) nutrients as per Fertilizer Recommendation Guide (FRG, 2018), $\mathrm{T}_{2}=\mathrm{T}_{1}+25 \% \mathrm{~N}$ of FRG, $\mathrm{T}_{3}=\mathrm{T}_{1}+25 \%$ NPof FRG, $\mathrm{T}_{4}=\mathrm{T}_{1}+25 \%$ NKof FRG, $\mathrm{T}_{5}=\mathrm{T}_{1}$ $+25 \%$ PKof FRG, $\mathrm{T}_{6}=\mathrm{T}_{1}+25 \%$ NPKof FRG, $\mathrm{T}_{7}=75 \%$ of $\mathrm{T}_{1}$ and $\mathrm{T}_{8}=$ Native fertility (Control) were tested in the experiment. The whole amount of $\mathrm{P}, \mathrm{K}, \mathrm{S}, \mathrm{Zn}$, and half of $\mathrm{N}$ were applied at the time of final land preparation and the remaining $\mathrm{N}$ was applied 20 days after the sowing of mustard seeds. The amount of nutrients used in the treatment combination is given in Table 2.

Table 1. Native fertility status of the experimental plot (composite topsoil $(0-30 \mathrm{~cm})$ samples collected from the experimental plots at the Central Research Farm, BARI, Gazipur

\begin{tabular}{cccccc}
\hline $\mathrm{pH}$ & $\begin{array}{c}\text { TOC } \\
(\%)\end{array}$ & $\begin{array}{c}\text { TSN } \\
(\%)\end{array}$ & $\begin{array}{c}\mathrm{P}_{\text {Olsen }} \\
(\mathrm{ppm})\end{array}$ & $\begin{array}{c}\mathrm{K}_{\text {exch. }} \\
\left(\mathrm{cmol} \mathrm{kg}^{-1}\right)\end{array}$ & $\begin{array}{c}\mathrm{S} \\
\left(\mu \mathrm{g} \mathrm{g}^{-1}\right)\end{array}$ \\
\hline 5.9 & 1.41 & 0.089 & 8.4 & 0.21 & 9.4 \\
\hline
\end{tabular}

NB: TOC $=$ Total organic carbon and TSN=Total soil nitrogen

The crop was harvested at 80 days after sowing when the pods showed ripening signs. Ten plants were selected randomly from each plot in such a way that the border effect was avoided for the higher level of precision.Data on plant height $(\mathrm{cm})$, number of branches plant ${ }^{-1}$, number of siliquaplant ${ }^{-1}$, weight of fresh plant $(\mathrm{g})$, weight of fresh stem $(\mathrm{g})$, weight of dry stem $(\mathrm{g})$, weight of fresh siliqua $(\mathrm{g})$, weight of dry siliqua (g), weight of 100 pod (siliqua) (g), 1000-seedweight, stover yield and seedyield were collected following standard methods.Seedand stover weight was taken from the $6-\mathrm{m}^{2}$ area from the center of each plot excluding border area. After threshing and cleaning, the weight was taken by finetuning electric balance and converted to kilogram $(\mathrm{kg})$ in a dry weight basis. 
Table 2.Treatment combinations of different nutrients in the experimental field at the Central Research Farm,BARI, Gazipur

\begin{tabular}{ccccccc}
\hline Treatments & \multicolumn{7}{c}{ Treatment combination } \\
\cline { 2 - 6 } & $\mathrm{N}$ & $\mathrm{P}$ & $\mathrm{K}$ & $\mathrm{S}$ & $\mathrm{Zn}$ & $\mathrm{B}$ \\
\cline { 2 - 6 } & 90 & 25 & 60 & 15 & 2 & 1 \\
\hline $\mathrm{T}_{1}$ & 112.5 & 25 & 60 & 15 & 2 & 1 \\
$\mathrm{~T}_{2}$ & 112.5 & 31.25 & 60 & 15 & 2 & 1 \\
$\mathrm{~T}_{3}$ & 112.5 & 25 & 75 & 15 & 2 & 1 \\
$\mathrm{~T}_{4}$ & 90 & 31.25 & 75 & 15 & 2 & 1 \\
$\mathrm{~T}_{5}$ & 112.5 & 31.25 & 75 & 15 & 2 & 1 \\
$\mathrm{~T}_{6}$ & 68 & 19 & 45 & 11.25 & 1.5 & 0.75 \\
$\mathrm{~T}_{7}$ & \multicolumn{7}{c}{ Native fertility } \\
$\mathrm{T}_{8}$ & \multicolumn{7}{c}{} \\
\hline
\end{tabular}

\section{Chemical analysis of seedand stover}

Preparation of samples: Seedand stover samples were dried in an oven at $65^{\circ} \mathrm{C}$ for 48 hours and then ground by a grinding machine to pass through a 20 mesh sieve and stored in small paper bags into desiccators. Then the samples were analyzed for N, P, K, and S content.

\section{Digestion of samples with nitricperchloric acid}

Half gram dried sample was transferred into a dry clean $100 \mathrm{ml} \mathrm{Kjeldahl} \mathrm{flask.} \mathrm{A} 10 \mathrm{ml}$ of di-acid $\left(\mathrm{HNO}_{3}: \mathrm{HClO}_{4}\right)$ in the ratio of 2: 1 was added. After leaving for a while, the flask was heated at a temperature slowly to rise to $200^{\circ} \mathrm{C}$. Heating was momentarily stopped when the dense white fumes of $\mathrm{HClO}_{4}$ occurred and after cooling, $6 \mathrm{ml}$ of $6 \mathrm{~N} \mathrm{HCl}$ was added to it. The contents of the flask were boiled until they became sufficiently clean and colorless. P, K, and S contents of the flask were determined from this digest.

\section{Digestion of samples with sulfuric acid}

An amount of $100 \mathrm{mg}$ oven-dry ground sample was taken in a $100 \mathrm{ml} \mathrm{Kjeldahl} \mathrm{flask} \mathrm{and} 1.1 \mathrm{~g}$ catalyst mixture $\left(\mathrm{K}_{2} \mathrm{SO}_{4}: \mathrm{CuSO}_{4} 5 \mathrm{H}_{2} \mathrm{O}\right.$ : selenium) in the ratio (10: 1: 0.1$), 2 \mathrm{ml} 30 \% \mathrm{H}_{2} \mathrm{O}_{2}$ and $3 \mathrm{ml}$ conc. $\mathrm{H}_{2} \mathrm{SO}_{4}$ was added into the flask. The flask was swirled and allowed to stand for about 10 minutes. After that, the flask was heated and continued heating until the digest became colorless. After cooling, the digest was transferred into a $100 \mathrm{ml}$ volumetric flask and made up to the mark with distilled water. A blank sample with requisite reagents was prepared in similarly. This digest was used for the estimation of total $\mathrm{N}$ following standard procedure.

\section{Measurement of $N, P, K$ and $S$ contents in seed}

\section{Nitrogen determination}

Nitrogen content of seedof plant was analyzed by Micro-kjeldahl method (Bremner and Mulvaney, 1982). Exactly $0.1 \mathrm{~g}$ sample was digested in a fume hood with $10 \mathrm{ml}$ concentrated $\mathrm{H}_{2} \mathrm{SO}_{4}$ in presence of $\mathrm{K}_{2} \mathrm{SO}_{4}$ catalyst mixture $\left(\mathrm{K}_{2} \mathrm{SO}_{4}: \mathrm{CuSO}_{4}: \mathrm{Se}=10: 1: 1\right)$. The digest was then transferred to a distillation flask and $5 \mathrm{ml} 40 \% \mathrm{NaOH}$ was added. Nitrogen was estimated by titrating the distillate trapped in the $\mathrm{H}_{3} \mathrm{BO}_{3}$ indicator solution with $0.02 \mathrm{~N} \mathrm{H}_{2} \mathrm{SO}_{4}$.

\section{Phosphorus determination}

The total phosphorus content of different plant parts wasdetermined by using Vanadomolybdate method (Yoshida et al., 1972). Dried plant materials were digested with concentrated $\mathrm{HNO}_{3}$ and $\mathrm{HClO}_{4}$ 
(Nitric per-chloric acid) mixture for the determination of total P content. Total P content in the extract was determined by Jackson (1973) using a double beam spectrophotometer at 440nm wavelength.

\section{Potassium determination}

Total potassium was also determined by using the Per-chloric acid digestion assay method (Yamakawa, 1992). Dried plant materials were digested with concentrated $\mathrm{HNO}_{3}$ and $\mathrm{HClO}_{4}$ (Nitric perchloric acid) mixture for determination of total $\mathrm{K}$ content. The concentration of $\mathrm{K}$ was determined by the atomic absorption spectrophotometer at $766 \mathrm{~nm}$ wavelength.

\section{Sulfur determination}

Dried plant materials were digested with concentrated $\mathrm{HNO}_{3}$ and $\mathrm{HClO}_{4}$ (Nitric per-chloric acid) mixture for determination of total $\mathrm{S}$ content which is known as nitric per-chloric acid digestion method. Sulfur was estimated through theturbid metric method using $\mathrm{BaCl}_{2} .2 \mathrm{H}_{2} \mathrm{O}$ by double Beam Spectrophotometer at $420 \mathrm{~nm}$ wavelength.

\section{Statistical analysis}

Data recorded in the experiments were statistically analyzed following procedures described by Gomez and Gomez (1984). Analysis of variance (ANOVA) was conducted using statistical software MSTAT$\mathrm{C}$ and Means were compared with the least significant difference (LSD) test.

\section{Results and Discussion}

The influences on the agronomic parameters, yield attributes,and yield; such as plant height, dry weight of stem, fresh weight of siliqua, dry weight of siliqua, 100-siliqua weight, 1000-seed weight, seedyield, stover yield are shown in different tables and figures below.

\section{Plant height}

The plant height of mustard was significantly influenced by different nutrition levels (Table 3). The maximum plant $(91.07 \mathrm{~cm})$ was recorded in $\mathrm{T}_{6}$ treatment $\left(\mathrm{T}_{1}+25 \%\right.$ NPK i.e., recommendeddose $+25 \%$ NPK chemical fertilizer) which was statistically similar to all treatments except $\mathrm{T}_{7}$ and control treatment $\left(\mathrm{T}_{8}\right)$ with lowest plant height $(72.68 \mathrm{~cm})$. Ali and Ullah $(1995)$ reported that the tallest mustard plant was found with the application of $120 \mathrm{~kg} \mathrm{~N} \mathrm{ha}^{-1}$. The increase in plant height in these treatments was attributed to the availability of optimum nutrients throughout the growing season which might render the optimum and balanced nutrients from chemical fertilizer that reflected in plant height. However, the addition of extra $\mathrm{N}, \mathrm{P}$, and $\mathrm{K}$ had no significant effect on plant height.

\section{Number of branches plant ${ }^{-1}$}

Nutrients rates had a significant influence to produce branches in plants (Table 3). The maximumnumber of branchesplant ${ }^{-1}$ (7.20) was recorded in $\mathrm{T}_{6}$ treatment which was at par with $\mathrm{T}_{2}$ $\left(\mathrm{T}_{1}+25 \% \mathrm{~N}\right)$ and $\mathrm{T}_{5}\left(\mathrm{~T}_{1}+25 \% \mathrm{PK}\right)$ but statistically higher from the other treatments. The lowest number of branches (3.92) was recorded in $\mathrm{T}_{8}$ treatment where no nutrition was applied. The results are in agreement with the findings of Shuklaet al. (2002) who found that the application of mixed fertilizer (NPKS) increased the number of branches in the mustard plant.The nutrient helps in initiating buds in plants. These buds ultimately become active branches from where leaves emerge as photosynthetic organs and the flowering nodes are developed. Thus it plays a vital role in increasing the crop yield.

\section{Dry weight of stem plant ${ }^{-1}$}

As shown in Table 3, the nutrient response on stem dry weight was significant. The highest stem dry weight was observed in $\mathrm{T}_{6}$ treatment $\left(25.74 \mathrm{~g} \mathrm{plant}^{-1}\right)$ which is statistically different from all other treatments. In contrast, the lowest value of stem dry weight $\left(9.72 \mathrm{~g} \mathrm{plant}^{-1}\right)$ was found in $\mathrm{T}_{8}$ treatment. 
The possible reason behind might be this due to an increase in nutrition level the photosynthesis rate increases as a result of more dry matter accumulation occurs and ultimately stem dry weight increases. The results were in alignment with Bhagawanet al. (1996).

Table 3. Effect of nutrient rates on agronomic parameters of the short duration mustard BARI Sarisha14

\begin{tabular}{lccccc}
\hline \multicolumn{1}{c}{ Treatments } & $\begin{array}{c}\text { Plant height } \\
(\mathrm{cm})\end{array}$ & $\begin{array}{c}\text { Branches } \\
\text { plant }^{-1}(\text { no. })\end{array}$ & $\begin{array}{c}\text { Dry weight } \\
\text { of stem }(\mathrm{g})\end{array}$ & $\begin{array}{c}\text { Fresh weight } \\
\text { of siliqua }(\mathrm{g})\end{array}$ & $\begin{array}{c}\text { Dry weight } \\
\text { of siliqua } \\
(\mathrm{g})\end{array}$ \\
\hline $\begin{array}{l}\mathrm{T}_{1}=100 \% \mathrm{NPKS} \\
(\mathrm{STB})\end{array}$ & $83.53 \mathrm{ab}$ & $5.70 \mathrm{bc}$ & $20.26 \mathrm{bc}$ & $124.52 \mathrm{~d}$ & $23.61 \mathrm{~d}$ \\
$\mathrm{~T}_{2}=\mathrm{T}_{1}+25 \% \mathrm{~N}$ & $82.86 \mathrm{ab}$ & $6.03 \mathrm{abc}$ & $19.94 \mathrm{bc}$ & $148.04 \mathrm{~b}$ & $28.87 \mathrm{~b}$ \\
$\mathrm{~T}_{3}=\mathrm{T}_{1}+25 \% \mathrm{NP}$ & $87.53 \mathrm{ab}$ & $5.86 \mathrm{bc}$ & $20.24 \mathrm{bc}$ & $147.44 \mathrm{~b}$ & $28.03 \mathrm{~b}$ \\
$\mathrm{~T}_{4}=\mathrm{T}_{1}+25 \% \mathrm{NK}$ & $88.33 \mathrm{ab}$ & $5.17 \mathrm{c}$ & $20.35 \mathrm{~b}$ & $137.46 \mathrm{c}$ & $25.17 \mathrm{~cd}$ \\
$\mathrm{~T}_{5}=\mathrm{T}_{1}+25 \% \mathrm{PK}$ & $91.00 \mathrm{a}$ & $6.73 \mathrm{ab}$ & $22.03 \mathrm{~b}$ & $151.56 \mathrm{~b}$ & $28.29 \mathrm{~b}$ \\
$\mathrm{~T}_{6}=\mathrm{T}_{1}+25 \% \mathrm{NPK}$ & $91.07 \mathrm{a}$ & $7.20 \mathrm{a}$ & $25.74 \mathrm{a}$ & $180.25 \mathrm{a}$ & $33.31 \mathrm{a}$ \\
$\mathrm{T}_{7}=75 \%$ of $\mathrm{T}_{1}$ & $79.40 \mathrm{bc}$ & $4.83 \mathrm{~cd}$ & $17.37 \mathrm{c}$ & $105.57 \mathrm{e}$ & $17.39 \mathrm{e}$ \\
$\mathrm{T}_{8}=$ Control & $72.68 \mathrm{c}$ & $3.92 \mathrm{~d}$ & $9.72 \mathrm{~d}$ & $50.24 \mathrm{f}$ & $10.23 \mathrm{f}$ \\
\hline $\mathrm{CV}(\%)$ & 6.08 & 4.71 & 8.64 & 3.12 & 5.15 \\
$\mathrm{SE}$ & 4.19 & 4.38 & 1.38 & 3.32 & 1.01 \\
\hline
\end{tabular}

Means followed by a common letter(s) are not significant at $5 \%$ level by of probability

\section{Fresh weight of siliqua plant ${ }^{-1}$}

The fresh weight of siliquaplant ${ }^{-1}$ at different nutrient levels showed a significant result (Table 3 ). The highest $\%$ relative fresh weight of siliqua was observed in $\mathrm{T}_{6}\left(180.25 \mathrm{~g} \mathrm{plant}^{-1}\right)$ where $100 \%$ recommended dose of fertilizer and an additional $25 \%$ NPK were used which is statistically different from all other treatments. In contrast, the lowest value of siliqua fresh weight $\left(50.24 \mathrm{~g} \mathrm{plant}^{-1}\right)$ was found in $T_{8}$ treatment. The results indicated that siliqua fresh weight increased in $T_{6}$ treatment, due to the higher amount of supplied nutrients which might encourage the photosynthesis rate. Similar outcomes were obtained earlier by Bhagawanet al. (1996) and Mondalet al. (1997).

\section{Dry weight of siliquaplant ${ }^{-1}$}

It is proved from the results that different nutrition has a significant effect on the siliqua dry weight per plant. In Table 3 it observed that the highest siliqua dry weight $(33.31 \mathrm{~g})$ was observed in $\mathrm{T}_{6}$ treatment which is statistically different from all other treatments and $T_{8}$ showedthe lowest siliqua dry weight $(10.23 \mathrm{~g})$. The possible reason might be that due to less in nutrient level lessen the photosynthesis rate of the plant also decreases resulting in less accumulation of photosynthates and ultimately giving the lowest siliqua dry weight in $\mathrm{T}_{8}$ treatment.

\section{Number of siliquaeplant ${ }^{-1}$}

The number of siliquae plant ${ }^{-1}$ is one of the most important yield contributing characters in mustard. The number of siliquaplant ${ }^{-1}$ was significantly affected by different levels of fertilizers (Table 4). The higher number of total siliquaplant ${ }^{-1}(80.87)$ was recorded with plants grown under $\mathrm{T}_{6}$ treatment which is statistically different fromall other treatments. In contrast, the lower number of total siliqua plant ${ }^{-1}$ (38.67) was recorded in plants grown under $\mathrm{T}_{8}$ treatment. This might be since nitrogen in the presence of other nutrients plays a vital role in both cell division and cell enlargement which might occur in this study. The results confirmed the findings of Singh et al. (1985). 


\section{Seeds siliqua ${ }^{-1}$}

The effect of different levels of nutrition on the number of seeds siliqua ${ }^{-1}$ was statistically significant (Table 4). The highest number of seeds siliqua ${ }^{-1}(35.90)$ was obtained from the treatment $\mathrm{T}_{6}$ that statistically similar toall treatments except $\mathrm{T}_{4}, \mathrm{~T}_{5}$, and $\mathrm{T}_{8}$. The lowest number of seeds seliqua ${ }^{-1}(29.60)$ was obtained from the $\mathrm{T}_{8}$ treatment. Additional nitrogen in the presence of other nutrients increased the leaves area which leads to higher total photosynthesis and higher translocation of assimilating from vegetative to reproductive part. These results were in alignment with Shuklaet al. (2002)who found that increased fertility levels increased seedspersiliqua.

Table 4. Effect of nutrient rates on yield attributes and stover yield of mustard var. BARI Sarisha-14

\begin{tabular}{lccccc}
\hline Treatment & $\begin{array}{c}\text { Siliquaeplant } \\
\text { (no.) }\end{array}$ & $\begin{array}{c}\text { Seeds siliqua } \\
\text { (no.) }\end{array}$ & $\begin{array}{c}100 \text {-siliqua } \\
\text { weight }(\mathrm{g})\end{array}$ & $\begin{array}{c}\text { 1000-seed } \\
\text { weight }(\mathrm{g})\end{array}$ & $\begin{array}{c}\text { Stover yield } \\
\left(\mathrm{t} \mathrm{ha}^{-1}\right)\end{array}$ \\
\hline $\mathrm{T}_{1}=100 \% \mathrm{NPKS}$ & $70.20 \mathrm{~b}$ & $32.60 \mathrm{abc}$ & $22.67 \mathrm{bc}$ & $2.98 \mathrm{a}$ & $2.40 \mathrm{~d}$ \\
$(\mathrm{STB})$ & & & & & \\
$\mathrm{T}_{2}=\mathrm{T}_{1}+25 \% \mathrm{~N}$ & $66.20 \mathrm{~b}$ & $33.76 \mathrm{ab}$ & $21.67 \mathrm{bc}$ & $2.96 \mathrm{a}$ & $2.55 \mathrm{c}$ \\
$\mathrm{T}_{3}=\mathrm{T}_{1}+25 \% \mathrm{NP}$ & $71.33 \mathrm{~b}$ & $32.20 \mathrm{abc}$ & $23.33 \mathrm{~b}$ & $3.12 \mathrm{a}$ & $2.40 \mathrm{~d}$ \\
$\mathrm{~T}_{4}=\mathrm{T}_{1}+25 \% \mathrm{NK}$ & $56.13 \mathrm{c}$ & $29.77 \mathrm{c}$ & $25.67 \mathrm{ab}$ & $2.94 \mathrm{a}$ & $2.31 \mathrm{e}$ \\
$\mathrm{T}_{5}=\mathrm{T}_{1}+25 \% \mathrm{PK}$ & $62.07 \mathrm{bc}$ & $32.17 \mathrm{bc}$ & $25.67 \mathrm{ab}$ & $2.92 \mathrm{a}$ & $2.62 \mathrm{~b}$ \\
$\mathrm{~T}_{6}=\mathrm{T}_{1}+25 \% \mathrm{NPK}$ & $80.87 \mathrm{a}$ & $35.90 \mathrm{a}$ & $26.67 \mathrm{a}$ & $3.16 \mathrm{a}$ & $2.96 \mathrm{a}$ \\
$\mathrm{T}_{7}=75 \%$ of $\mathrm{T}_{1}$ & $55.80 \mathrm{c}$ & $32.60 \mathrm{abc}$ & $21.33 \mathrm{c}$ & $2.82 \mathrm{ab}$ & $2.10 \mathrm{f}$ \\
$\mathrm{T}_{8}=$ Control & $38.67 \mathrm{~d}$ & $29.60 \mathrm{c}$ & $21.00 \mathrm{c}$ & $2.52 \mathrm{~b}$ & $1.40 \mathrm{~g}$ \\
\hline $\mathrm{CV}(\%)$ & 4.71 & 6.58 & 5.04 & 5.89 & 11.62 \\
$\mathrm{SE}_{(0.05)}$ & 4.38 & 1.73 & 0.06 & 4.57 & 2.67 \\
\hline
\end{tabular}

Means followed by a common letter(s) are not significant at $5 \%$ level by of probability

\section{Siliqua weight}

Different treatments showed significant variation in respect of 100 -siliqua weight (Table 4). The maximum 100-siliqua weight ( $26.67 \mathrm{~g}$ ) was observed in the case of $\mathrm{T}_{6}$ treatment where more nutrition was added and which is statistically similar to $\mathrm{T}_{4}$ and $\mathrm{T}_{5}$ treatments but different from all other treatments. The lowest 100 -siliqua weight $(21.0 \mathrm{~g})$ was observed in $\mathrm{T}_{8}$ treatment. These results confirmed with the findings of Hossainet al. (1997).

\section{Seed weight}

It is noted that 1000 -seed weight was significantly influenced by different levels of nutrients (Table 4). The highest 1000 -seed weight $(3.16 \mathrm{~g})$ was recorded with $\mathrm{T}_{6}$ treatment which is statistically similar toall other treatments except $\mathrm{T}_{7}$ and $\mathrm{T}_{8}$ treatment. The lowest 1000 -seed weight $(2.52 \mathrm{~g})$ was recorded in the control. Seed weight is genetically characteristics, however, it was influenced the nutrient rates. The results indicated that the 1000-seed weight of mustard increased with increased nutrient rates. These results were corroborating with findings of Singh et al. (1985) who found that 1000-seed weight was increased withthe applicationof additional nutrients.

\section{Seed yield}

The data regarding mustard seed yield as influenced by different fertilizer rates (Figure 1). The tested fertilizer treatments affected mustard seed yield significantly. The highest mustard seed yield $\left(1.68 \mathrm{t} \mathrm{ha}^{-}\right.$ ${ }^{1}$ ) was produced from the treatment $\mathrm{T}_{6}$ where $25 \%$ extra NPK was added over the $100 \%$ STB fertilizer rate. This yield value was statistically higher than all other treatments except the $\mathrm{T}_{3}$ treatment which was statistically similar. The native nutrient treatment $\mathrm{T}_{8}$ produced the lowest mustard seed yield $(0.89 \mathrm{t}$ 
$\mathrm{ha}^{-1}$ ). Due to enhanced growth attributes that crop diverted the photosynthates to reproductive organs for the formation of seeds of large size and number that ultimately increased the yield. These results were in corroborates with those reported by Tomaret al. (1997), Jagviret al. (2004)and Rao et al. (2006).

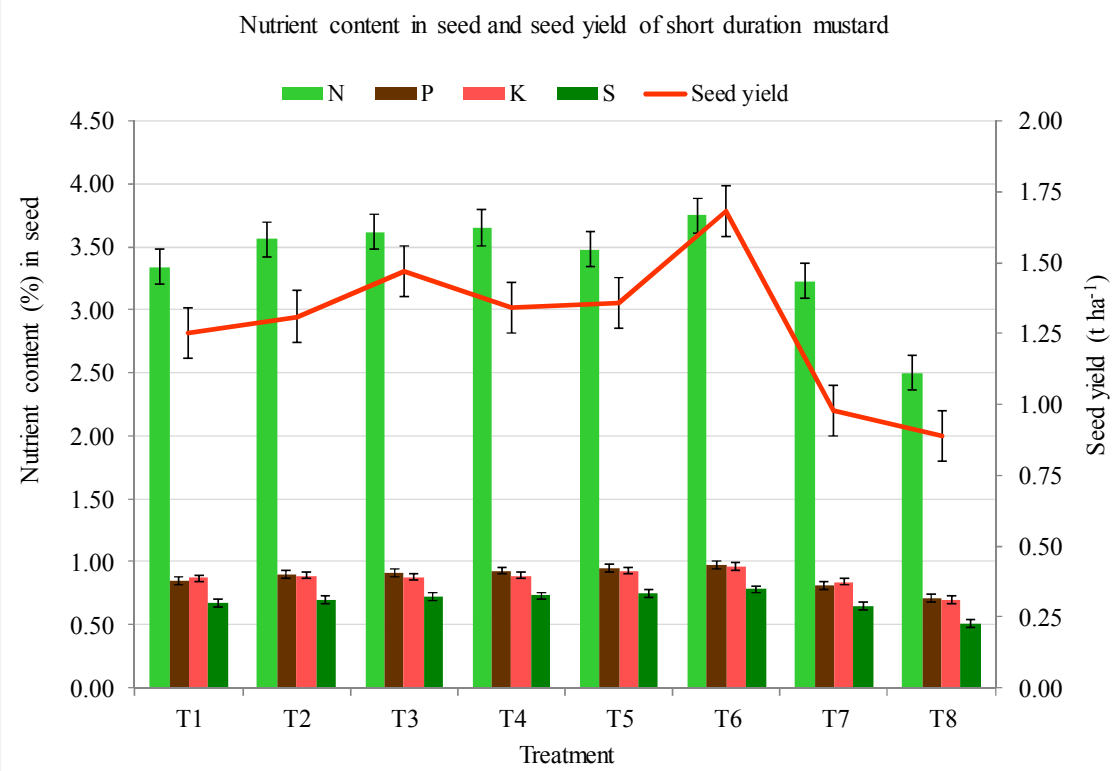

Fig. 1. Seed yield and nutrient contents in the seedof the short duration mustard var.BARI Sarisha-14 as influenced by nutrient rates.

\section{Nutrient content in seed}

Nutrients (N, P, K, and S) content in seedof short duration mustard was significantly affected by the nutrient rates (Figure 1). The highest amount of all the nutrients content was found in the treatment T6 that was followed by $\mathrm{T}_{3}$ and $\mathrm{T}_{4}$. The highest amount of $\mathrm{N}, \mathrm{P}, \mathrm{K}$, and $\mathrm{S}$ content in seedof the treatment $\mathrm{T}_{6}$ was $3.75,0.97,0.96$, and $0.78 \%$, respectively. Nutrients content was the lowest in $\mathrm{T}_{8}$ where fertilizers not applied and it was followed by $\mathrm{T}_{7}$ where $25 \%$ less amount fertilizers applied from $\mathrm{T}_{1}$ (STB). The lowest amount of N, P, K, and S content in seedof the treatment T8 was 2.50, 0.71, 0.70 and $0.51 \%$, respectively. Nutrients content had a harmonic relationship withseedyield. The results revealed that a higher amount of nutrient addition positively influenced to accumulate a higher amount of nutrient in seed. These results confirmed with the findings of Yadavet al. (2017).

\section{Stover yield}

Stover yield of mustard was significantly influenced by the application of different doses of chemical fertilizers (Table 4). The higheststover yield $\left(2.96 \mathrm{tha}^{-1}\right)$ was recorded in treatment $\mathrm{T}_{6}$ receiving $25 \%$ extra NPK over the $100 \%$ STB fertilizer rate and the lowest stoveryield $\left(1.40 \mathrm{t} \mathrm{ha}^{-1}\right)$ was recorded in $\mathrm{T}_{8}$ treatment. This result was mainly because an optimum fertilizer facilitated maximum utilization of nutrients which enhanced total dry matter production and development of other yield contributing components. The results also confirmed the findings of Jagviret al. (2004) which agreed well with the results of the present study. 


\section{Percent increase in yield of grain and stover over controltreatment}

The seed yield of mustard increased significantly due to the application of different levels of nutrients. The increase of seed yield over control (Native fertility) ranges from 4.49 to $88.76 \%$ (Figure 2) and the highest yield increase $\left(88.76 \%\right.$ ) showed in $\mathrm{T}_{6}$ treatment receiving $25 \%$ extra NPK over $100 \% \mathrm{STB}$ fertilizer rate and the lowest yieldincrease in $\mathrm{T}_{7}$ treatment.In the case ofstover yield, percent increase over the control ranged from 50 to $111.42 \%$, and the highest stover yield increase was found in $\mathrm{T}_{6}$ treatment $(111.42 \%)$ and lowest in $\mathrm{T}_{7}$ treatment $(50 \%)$.

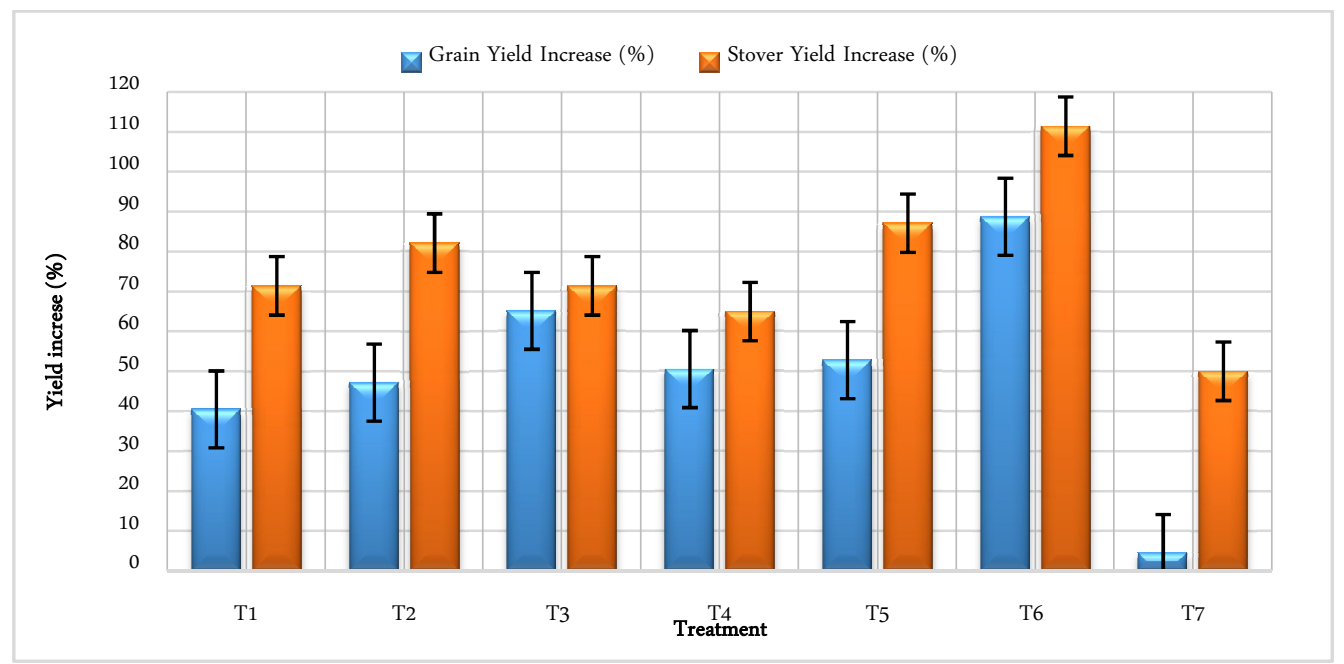

Fig.2.Seed (grain) and stover yield of mustard var. BARI Sarisha-14 increased (\%) in the fertilized treatments $\left(T_{1}\right.$ to $\left.T_{7}\right)$ over the controltreatment $\left(T_{8}\right)$.

\section{Conclusion}

In the present study, it showed that the treatment $\mathrm{T}_{6}(100 \%$ recommended fertilizers based on soil test along with an additional dose of $25 \%$ NPK) gave the highest seed yield of short-duration mustard var. BARI Sarisha-14. Most of the growth parameters and yield components were also higher in this treatment which positively influenced seed and stover yields. Short-duration mustard var. BARI Sarisha-14 is one of the important crop components in the four-cropping pattern comprising MustardMungbean-T.aus-T.aman. The findings concluded that an additional 25\% NPK along withSTB fertilizer dose recommended for attaining better yield ofshort-duration mustard variety.

\section{References}

Ali, M.H. and M.J. Ullah. 1995. Effect of different levels and methods of nitrogen application on growth and yield of rapeseed (Brassica campestris L.).Ann. Bangladesh Agri. 5(2): 115-120.

BBS(Bangladesh Bureau of Statistics). 2018. Yearbook of Agricultural Statistics-2017.Statistical Pocket Book of Bangladesh, Ministry of Planning, Government of People's Republic of Bangladesh, Dhaka. pp.123-124.

Bhagawan, S., K.Vinod, B. Singh and V. Kumar. 1996. Response of Indian mustard (B. juncea) to nitrogen and sulfur application under rainfed condition. Indian J. Agron. 41(2): 286-289. 
Bremner, J.M. and C.S. Mulvaney.1982. Total Nitrogen. In: Methods of Soil Analysis, Part II. 2nd Ed. Amer. Soc. Agron. Inc. USA. pp.595-622.

FRG (Fertilizer Recommendation Guide). 2018. Fertilizer Recommendation Guide. Published by BARC, Farm gate, Dhaka. pp.1-257.

Gomez, K.A. andA.A. Gomez. 1984. Statistical Procedures for Agricultural Research. John Wiley and Sons. Inc. New York. USA. pp.97-423.

Hossain,M.A., M.R. Siddique and M.A. Siddique. 1997. Effect of nitrogen on yield and yield components of some promising varieties of mustard. Bangladesh J. Agric. 22: 9-15.

Jagvir, S., D. Monga and M.S. Deshmuch. 2004. Direct and residual effect of sulfur on growth, yield and quality of cotton (Gossypiumhirsiutum) and mustard (Brassica juuncea) cropping system. J. Cotton Res. Dev. 18(2): 172-174.

Miah, M.M.U. and Z. Karim. 1995. Extension of integrated plant nutrition system (IPNS) at farm level in Bangladesh. In. F.J. Dent and S. Gangwani (Eds.) Progress and Problems in the Extension of Integrated Plant Nutrient Systems (IPNS) at Farm Level in Asia. FAO Publication No. 12. pp.2942.

Mondal, P., M. Podder, M.A. Hossain and M.A. Khaleque. 1997. Effect of time ofnitrogen application on the yield and yield components of rapeseed. Bangladesh J. Agril. Sci. 2(2): 49-52.

Rao, K.T., G.J. Naidu and G. Subbaiah. 2006. Effect of foliar application of micronutrient on yield and yield attributes on Indian mustard (Brassica juuncea L.). Agril. Sci. Digest. 26(2): 144-146.

Saweda, L.O.L., B.T. Omonona, A. Sanou andW.O. Ogunleye.2017. Is increasing inorganic fertilizer use for maize production in SSA aprofitable proposition? Evidence from Nigeria. Food Policy. 67:41-51.

Shukla, R.K., A. Kumar,B.S. Mahapatra and B.Kandpal. 2002. Integrated nutrient management practices in relation to morphological and physiological determinants of seed yield in Indian mustard (Brassica juncea L.). Indian J. Agric. Sci. 72(11): 670-612.

Singh, S.M., D.R. Dahiya and R.P. Singh. 1985. Effect of varying rectangularities, nitrogen and varieties and yield attributes of mustard. Indian J. Agron. 30(1): 78-83.

Tomar, T., S. Singh, S. Kumar and S.Tomar. 1997. Response of Indian mustard (Brassica juncea) to nitrogen, phosphorus and sulfur fertilization. Indian J. Agron. 42(1): 148-151.

Yadav, K.G., C. Kushwaha,P.K. Singh, M. Kumar, S.K. Yadav and Nishant. 2017. Effect of nutrient management on yield and nutrient uptake by Indian mustard (Brassica juncea L). J.Pharmaco.Phytochem. SP1: 556-559.

Yamakawa, T. 1992. Laboratory Methods for Soil Science and Plant Nutrition. IPSA, JICA Project publication No. 2. IPSA, Gazipur, Bangladesh.

Yoshida, S., D.A. Forno, J.H. Cock and K.A. Gomez. 1972. Laboratory Manual for Physiological Studies of Rice. IRRI, Los Banos, Philippines. 